January 1989

\title{
Mead Johnson Award-1989
}

Follow this and additional works at: https://jdc.jefferson.edu/jeffjpsychiatry

Part of the Psychiatry Commons

Let us know how access to this document benefits you

\section{Recommended Citation}

(1989) "Mead Johnson Award-1989," Jefferson Journal of Psychiatry. Vol. 7 : Iss. 1 , Article 3.

DOI: https://doi.org/10.29046/JJP.007.1.008

Available at: https://jdc.jefferson.edu/jeffjpsychiatry/vol7/iss $1 / 3$

This Article is brought to you for free and open access by the Jefferson Digital Commons. The Jefferson Digital Commons is a service of Thomas Jefferson University's Center for Teaching and Learning (CTL). The Commons is a showcase for Jefferson books and journals, peer-reviewed scholarly publications, unique historical collections from the University archives, and teaching tools. The Jefferson Digital Commons allows researchers and interested readers anywhere in the world to learn about and keep up to date with Jefferson scholarship. This article has been accepted for inclusion in Jefferson Journal of Psychiatry by an authorized administrator of the Jefferson Digital Commons. For more information, please contact: JeffersonDigitalCommons@jefferson.edu. 


\section{Mead Johnson Award}

The Mead Johnson Award has been established to honor the best paper submitted to The Jefferson Journal of Psychiatry-A Resident Publication during each calendar year. An award of one thousand dollars is given to the chosen author, with an additional one thousand dollars to be given to the residency program or fellowship in which the author is enrolled. The winning submission will be selected by the Journal's editorial board from manuscripts submitted on any subject related to psychiatric practice and/or research. We invite authors to review the Information for Contributors section of this issue.

The editorial board of the Journal is proud to announce the recipient of the 1988 Mead Johnson Award: Althea Donovan, M.D. a graduate of the residency program in psychiatry at Jefferson Medical College, Thomas Jefferson University. Dr. Donovan's article entitled Termination and Transparency in Group Psychotherapy: A Resident's Perspective, can be found in the most recent issue (Vol. 6 , No. 2) of the journal.

\section{PAST HONOREES}

1987-Paul V. Trad, M.D.

Infant Depression: Nature Seeking Nurture

Cornell Medical Center-West Chester Division, Child Outpatient Department 